\title{
IMPLEMENTASI METODE SAVING MATRIX DALAM PENENTUAN RUTE TERBAIK UNTUK MEMINIMUMKAN BIAYA DISTRIBUSI
}

\author{
(UD. Roti Arsita)
}

\author{
D. B. Pailin \\ Program Studi Teknik Industri, Fakultas Teknik Universitas Pattimura, Ambon \\ Fhony M. Kaihatu \\ Program Studi Teknik Industri, Fakultas Teknik Universitas Pattimura, Ambon
}

\begin{abstract}
ABSTRAK
Proses pendistribusian produk Pabrik roti Arsita secara langsung menimbulkan batasan dalam kapasitas kendaraan, biaya distribusi, dan waktu kerja yang berpengaruh pada efisiensi distribusi perusahaan. Sebuah kajian dilakukan dengan tujuan mendapatkan pola distribusi optimal agar dapat meningkatkan efisiensi jarak tempuh, waktu, dan biaya distribusi yang terbaik bagi perusahaan. Metode Saving Matrix adalah metode yang digunakan untuk menentukan rute distribusi produk ke wilayah pemasaran dengan cara menentukan rute distribusi yang harus dilalui dan jumlah kendaran berdasarkan kapasitas dari kendaraan tersebut agar diperoleh rute terpendek dan biaya transportasi yang minimal. Salah satu algoritma yang dapat digunakan dalam menyelesaikan permasalahan ini adalah algoritma Clarke \& Wright Saving. Hasil yang diperoleh menggunakan algoritma Clarke \& Wright Saving menunjukkan bahwa perolehan rute awal perusahaan sebesar 535,97 km sedangkan dengan metode Algoritma Clarke \& Wright Saving sebesar 273,56 km sehingga adanya nilai penghematan jarak sebesar 262,42 km atau 48\%. Dari perhitungan total biaya distribusi rute awal adalah sebesar Rp 6.097.614,012 per bulan dan total biaya distribusi menggunakan Algoritma Clarke \& Wright Saving adalah Rp 4.581 .002 per bulan dan diperoleh penghemantan biaya per bulan sebesar Rp 1.516 .612 per bulan atau sebesar 24,8\% per bulan dan total waktu tempuh sebesar 17,96\% dari rute awal perusahaan.
\end{abstract}

Kata Kunci:Rute Optimal, Saving Matrix, Clarke \& Wright Saving

\begin{abstract}
The distribution process of Arsita Bread Factory products directly creates limitations in vehicle capacity, distribution costs, and working time which affect the company's distribution efficiency. A study was conducted with the aim of obtaining optimal distribution patterns in order to improve the efficiency of mileage, time, and the best distribution costs for the company. Saving Matrix Method is a method used to determine the product distribution route to the marketing area by determining the distribution route that must be traversed and the number of vehicles based on the capacity of the vehicle in order to obtain the shortest route and minimal transportation costs. One algorithm that can be used in solving this problem is the Clarke \& Wright Saving algorithm. The results obtained using the Clarke \& Wright Saving algorithm show that the initial route acquisition of the company is $535.97 \mathrm{~km}$ while the Clarke \& Wright Saving Algorithm method is $273.56 \mathrm{~km}$ so that the value of the distance savings is $262.42 \mathrm{~km}$ or $48 \%$. From the calculation of the total cost of the initial route distribution is IDR 6,097,614,012 per month and the total cost of distribution using the Clarke \& Wright Saving Algorithm is IDR 4,581,002 per month and obtained an increase in monthly cost of IDR 1,516,612 per month or $24.8 \%$ per month and total travel time of $17.96 \%$ of the company's initial route.
\end{abstract}

Key Words : Optimal route, , Saving Matrix, Clarke \& Wright Saving

\section{PENDAHULUAN}

Seiring dengan perkembangan zaman yang terus meningkat pesat dan diimbangi munculnya produkproduk yang lebih kreatif, berinovasi dan terus- menerus berkembang, perusahaan dituntut untuk terus berinovasi salah satu cara yaitu menjadikan penyaruran atau pendistribusian sebagai hal yang penting untuk dikembangkan karena pendistribusian yang baik maka produk yang dihasilkan akan sampai kepada konsumen dengan cepat, tepat dan dalam kondisi baik.

Distribusi merupakan suatu kegiatan untuk memindahkan produk dari pihak supplier ke pihak konsumen dalan suatu supply chain (Chopra, 2010 dalam Ikhsan A. dkk, 2013). Pendistribusian yang 
dilakukan haruslah diimbangi dengan penentuan rute yang tepat sehingga proses perpindahan produk yang optimasi. Banyak sekali rute yang dapat dipilih perusahaan dalam mendistribusikan produknya, dan membutuhkan biaya yang berbeda- beda pula, untuk itu butuh suatu metode yang dapat menganalisa pendistribusian produk agar lebih bisa meminimalisasi dari segi waktu, jarak, biaya dan tenaga (A. Effendi, 2016).

Pabrik roti Arsita memproduksi 2 jenis roti dengan varian rasa yaitu mocca dan cokelat dengan memproduksi sebanyak 7000 roti dalam sekali produksi. Di Ambon roti ini sudah cukup dikenal dan memiliki banyak retailer dalam memasarkan produk roti arsita diseluruh kota Ambon. Pada kota Ambon ada 5 pabrik pabrik roti saingan yang sudah lebih dikenal sehingga pabrik roti Arsita dapat menggunakan distribusi yang optimal sehingga produk yang dimiliki dapat sampai kepada konsumen dan dapat dipercaya.

Pabrik roti Arsita memenuhi permintaan yang ada menggunakan kendaraan angkut dalam pendistribusiannya yaitu sepeda motor yang sudah dimodifikasi sehingga memiliki tempat penyimpan yang lebih besar pada bagian belakang motor tersebut. Pabrik roti Arsita memiliki 5 alat angkut motor, Pendistribusian yang dilakukan dengan angkutan motor tersebut memiliki kapasitas angkut 1000 sampai 2000 roti dengan masing - masing rute atau jalur distribusinya. Pada kendaraan yang pertama jalur distribusinya adalah daerah Tulehu, Waai dan Liang untuk 93 retailer, kendaraan yang kedua jalur distribusinya adalah daerah Poka, Waiheru Tulehu, Tengah- Tengah dan Passo untuk 133 retailer, kendaraan ketiga jalur distribusinya adalah daerah Hitu dan Laha 80 retailer, kendaraan yang keempat jalur distribusinya adalah daerah Kebun Cengkeh, Batu Merah dan Ambon untuk 120 retailer dan kendaraan yang kelima jalur distribusinya adalah daerah Passo, Lateri dan Batu Merah untuk 56 retailer.

Dari rute yang telah dilakukan sebelumnya dapat diketahui bahwa terdapat 2 kendaraan dalam satu daerah dan jalur distribusi yang sama dan kendaraan 1 memiliki jalur distribusi terbanyak dengan jarak yang lebih jauh. Selain itu juga jumlah kendaraan yang banyak diimbangi dengan tenaga kerja dan biaya transportasi yaitu biaya bahan bakar kendaraan dan biaya tenaga kerja yang seharusnya dapat diminimumkan dan mengakibatkan pengiriman dilakukan lebih dari sehari dan terjadi keterlambatan produk untuk sampai kepada retailer-retailer.

Permintaan yang ada mengharuskan dilakukannya pendistribusian roti yang menimbulkan beberapa jalur pendistribusian yang jarak dan waktu yang berbeda-beda dan pemaksimalan kapasitas kendaraan. Penentuan rute yang baik dapat membantu produsen dalam mendistibusikan roti untuk sampai ke retailer dengan cepat, tepat dan dalam kondisi yang baik. Pemanfaatan kapasitas kendaraan yang dipakai dapat membantu dalam poses pendistribusian secara tepat sehingga roti untuk sampai ke retailer terselesaikan.

Vehicle Routing Problem (VRP) berkaitan dengan penentuan rute untuk permasalahan pendistribusian barang atau produk yang melibatkan lebih dari satu kendaraan dengan kapasitas tertentu untuk melayani sejumlah pelanggan dengan permintaannya masing-masing. Untuk memenuhi permintaan pelanggan dengan jumlah muatan yang tidak melampaui kapasitas, maka digunakan Capacitated Vehicle Routing Problem (CVRP) yaitu setiap kendaraan mempunyai kapasitas yang terbatas. Melakukan pendistribusian dalam setiap kendaraan pengangkut hanya dapat dilaksanakan sebanyak satu kali pengiriman yaitu dari depot kepelanggan kembali ke depot (Sari M. dkk, 2016).

Penetuan rute terpendek dapat diselesaikan dengan menggunakan metode saving matrix. Metode Saving Matrix merupakan metode yang digunakan dalam menentukan jalur/rute disribusi produk ke retailer dengan cara menentukan jalur yang harus dilalui dan jumlah alat angkut berdasarkan kapasitas dari alat angkut tersebut agar diperoleh jalur yang efisien dan biaya transportasi yang optimum. Metode Saving Matrix adalah metode untuk meminimumkan jarak atau waktu atau ongkos dengan mempertimbangkan kendala-kendala yang ada. Digunakan jarak sebagai fungsi tujuan apabila diketahui koordinat tujuan pengiriman, lalu jarak yang akan ditempuh oleh semua kendaraan akan diminimumkan (Pujawan, 2005 dalam Evelyn dkk,2015). Kelebihan dari metode saving matrix ini terletak pada kemudahan untuk dimodifikasi jika terdapat batasan waktu pengiriman, kapasitas kendaraan, jumlah kendaraan atau batasan lain yang memberikan solusi yang lebih baik untuk menyelesaikan penjadwalan pengiriman dengan praktis dan cepat (Yunarti, 2013 dalam Evelyn dkk, 2015).

Dengan menggunakan metode saving matrix diharapkan dapat membantu dan mengatasi permasalahan distribusi pada pabrik roti Arsita sehingga dapat diketahui rute efisien dan optimal dengan memaksimumkan kapasitas kendaraan yang bertujuan untuk meminimumkan biaya distribusi.

Tujuan dari penelitian ini adalah Dapat menganalisis sistem rute distribusi pada perusahaan saat ini, Dapat merancang usulan alternatif terbaik penentuan rute distribusi mengunakan metode Saving Matrix, Dapat meminimumkan biaya distribusi. 


\section{LANDASAN TEORI}

\section{Distribusi}

Distribusi sering digambarkan sebagai satu dari bauran pemasaran (4P) yaitu price, place, product, promotion dengan menempatkan produk pada tempat yang sesuai untuk pembelian (Kotler, 2000). Manajemen distribusi dan transportasi dapat disebut juga sebagai manajemen logistik atau distribusi fisik. Logistik modern dapat didefenisikan sebagai proses pengelolaan yang strategis terhadap pemindahan dan penyimpanan barang, suku cadang dan barang jadi dari para supplier, diantara fasilitas perusahaan dan kepada para pelanggan (Bowersox, 2006). Kegiatan transportasi dan distribusi bisa dilakukan oleh perusahaan manufaktur dengan membentuk bagian distribusi atau transportasi tersendiri atau diserahkan ke pihak ketiga. Dalam upayanya untuk memenuhi tujuan-tujuan di atas, siapapun yang melaksanakan (internal perusahaan atau mitra ketiga), manajemen distribusi dan transportasi pada umumnya melakukan sejumlah fungsi dasar yang terdiri dari (Pujawan, 2010):

A. Melakukan segementasi dan menentukan target service level.

B. Menentukan mode transportasi yang akan digunakan.

C. Melakukan konsolidasi informasi dan pengiriman.

D. Melakukan penjadwalan dan penentuan rute pengiriman.

E. Memberikan pelayanan nilai tambah.

F. Menyimpan persediaan.

G. Menangani pengembalian (return).

Dengan latar belakang praktek manajemen logistik tradisional dan perubahan lingkungan bisnis yangsemakin cepat, Supply Chain Management (SCM) merupakan salah satu konsep dalam rangka merespon persoalan tersebut. SCM menekankan pada pola terpadu menyangkut proses aliran produk dari supplier, manufaktur, retailer hingga pada konsumen akhir. Dalam konsep SCM ingin diperlihatkan bahwa rangkaian aktivitas antara supplier hingga konsumen akhir adalah dalam satu kesatuan tanpa sekat yang besar. Mekanisme informasi antara berbagai komponen tersebut berlangsung secara transparan. Dengan demikian dapat dikatakan bahwa SCM adalah suatu konsep menyangkut pola pendistribusian produk yang mampu menggantikan pola-pola pendistribusian produk secara tradisional (Pujawan, 2010).

Pada sistem transportasi modern, transportasi merupakan bagian integral dari fungsi dan aktivitas masyarakat. Terdapat hubungan yang sangat erat dengan gaya hidup, jangkauan, lokasi kegiatan produksi, pemenuhan barang-barang, dan pelayanan yang tersedia untuk konsumsi. Semakin berkembangnya peradaban manusia saat ini, mampu membuat transportasi menjadi satu kesatuan mata rantai kehidupan yang sangat berpengaruh dalam pembangunan masyarakat.

Dalam suatu jaringan fasilitas, transportasi merupakan suatu rantai mata penghubung. Beberapa tahun terakhir ini, manajemen transportasi mendapat banyak perhatian dari berbagai kalangan perusahaan. Hampir setiap perusahaan dari berbagai ukuran dipastikan mempunyai manajer yang secara penuh bertanggung jawab terhadap pengelolaan program transportasinya. Secara umum, sebuah perusahaan mempunyai tiga alternatif untuk menetapkan kemampuan trans-portasinya. Alternatif pertama mengenai armada peralatan yang dapat dibeli atau disewa. Kedua, kontrak khusus dapat diatur dengan spesialis transportasi untuk mendapatkan kontrak jasa-jasa pengang-kutan. Ketiga, sebuah perusahaan dapat memperoleh jasa-jasa dari suatu perusa-haan transportasi berijin (legally authorized) yang menawarkan pengang-kutan dari suatu tempat ke tempat lain dengan biaya tertentu. Ketiga bentuk transportasi ini dikenal sebagai swasta (private), kontrak (contract), dan angkutan umum (common carriage). Jika dilihat dari sudut pandang logistik, ada tiga faktor yang memegang peranan utama dalam menentukan kemampuan pelayanan transportasi, yaitu biaya, kecepatan, dan konsistensi (Bowersox, 1995).

\section{Vehicle Routing Problem (VRP)}

VRP pertama kali diutarakan oleh Dantzig dan Ramser. VRP adalah permasalahan dari penentuan rute yang akan dibentuk dari sejumlah konsumen didasarkanatas satu atau beberapa depot. Setiap konsumen akan dilayani oleh satu kendaraan dengan batasan-batasan tertentu dan rute tersebut diawali dan diakhiri pada depot. Beberapa contoh batasan-batasan yang diberikan adalah kapasitas kendaraan, keterbatasan aksesbilitas konsumen, permintan pick-ups delivery dan time windows atau kendala waktu.VRP berhubungan dengan pengiriman dan pengambilan barang.

Permasalahan VRP dapat dibedakan menjadi dua, yaitu permasalahan statis dan dinamis. Permasalahan statis adalah permintaan konsumen telah diketahui sebelumnya. Sedangkan permasalahan dinamis adalah permintaan konsumen yang selalu berubah-ubah. Hasil dari penyelesaian masalah VRP adalah rute seperti yang digambarkan pada gambar dibawah ini 


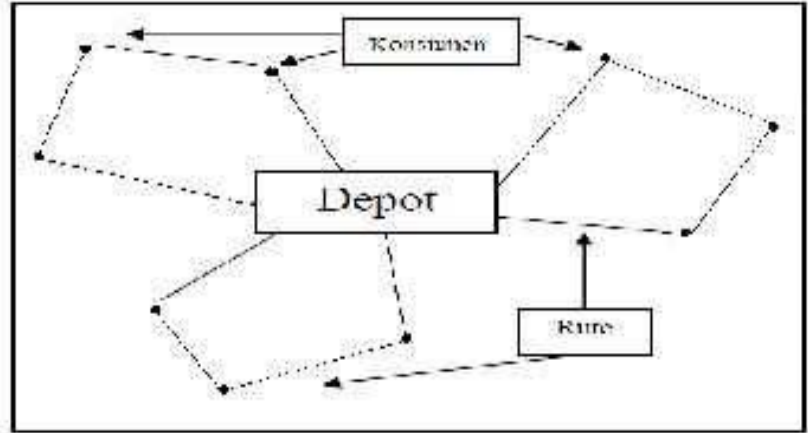

Contoh Hasil Pemecahan VRP

Salah satu permasalahan yang menarik di dalam pembahasan VRP adalah masalah mengenai Capacitated Vehicle Routing Problem (CVRP). CVRP merupakan kasus penentuan dari jumlah kendaraan yang bertujuan meminimalkan total jarak yang ditempuh semua rute, yang akan memenuhi kapasitas kendaraan dan melayani setiap konsumen. Salah satu jenis dari Vehicle Routing Problem yang dibatasi oleh kapasitas kendaraan. Input permasalahan CVRP adalah daftar jarak pelanggan, daftar permintaan tiap pelanggan dan kapasitas kendaraan.

\section{Teori Lintasan dan Sirkuit}

Lintasan adalah barisan berselang-seling dari simpul dan sisi yang berawal dengan simpul $V_{o}$ dan berakhir dengan simpul $V_{m}$. Lintasan terbagi atas 2 macam, yaitu lintasan terbuka dan lintasan tertutup. Lintasan terbuka adalah lintasan yang tidak berawal dan berakhir padasimpul yang sama, sedangkan lintasan tertutup adalah lintasan yang berawal dan berakhir pada simpul yang sama atau disebut juga sirkuit. Sirkuit terdiri dari 2 macam, yaitu :

A. Sirkuit Euler

Sirkuit euler adalah lintasan yang melalui masing-masing sisi di dalam graf tepat satu kali yang berawal dan berakhir pada simpul yang sama membentuk lintasan tertutup.

B. Sirkuit Hamilton

Sirkuit hamilton adalah lintasan yang melalui tiap simpul di dalam graf tepat satu kali yang berawal dan berakhir pada simpul yang sama membentuk lintasan tertutup.

\begin{tabular}{|c|c|c|c|c|}
\hline \multicolumn{5}{|c|}{ Perbedaan Lintasan Terbuka dan Tertutup ( Euler dan Hamilton ) } \\
\hline \multirow{2}{*}{ Lintasan } & \multicolumn{2}{|c|}{ Lintasan Terbuka } & \multicolumn{2}{|c|}{ Lintasan Tertutup (Sirkuit) } \\
\hline & Euler & Hamilton & Eul & Hamilton \\
\hline$(1,4,3,2)$ & Tidak & Ya & Tidak & Tidak \\
\hline$(1,2,3,4,1)$ & Tidak & Tidak & Tidak & Ya \\
\hline$(1,4,3,1,2,3)$ & Ya & Tidak & Tidak & Tidak \\
\hline
\end{tabular}

\section{SAVING MATRIX}

Metode Saving Matrix adalah metode yang digunakan untuk menentukan rute distribusi produk ke wilayah pemasaran dengan cara menentukan rute distribusi yang harus dilalui dan jumlah kendaran berdasarkan kapasitas dari kendaraan tersebut agar diperoleh rute terpendek dan biaya transportasi yang minimal. Metode Saving Matrix juga merupakan salah satu teknik yang digunakan untuk menjadwalkan sejumlah kendaraan terbatas dari fasilitas yang memiliki kapasitas maksimum yang berlainan. (Yunarti, 2013)

Kelebihan dari metode saving matrix ini terletak pada kemudahan untuk dimodifikasi jika terdapat Batasan waktu pengiriman, kapasitas kendaraan, jumlah kendaraan atau Batasan lain yang memberikan solusi yang lebih baik untuk menyelesaikan penjadwalan pengiriman dengan praktis dan cepat (Nusmese P, dkk, 2016) 


\section{Matriks Jarak}

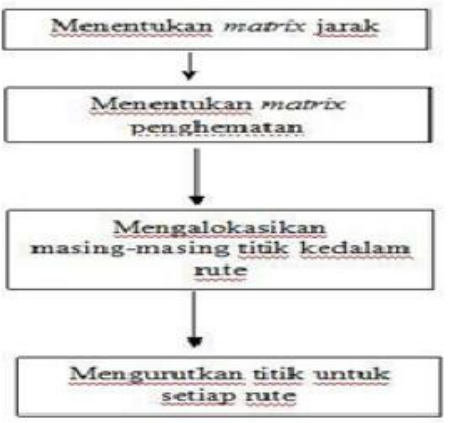

Skema Metode Saving Matrix

Matriks jarak menyatakan jarak antara tiap pasang lokasi yang di kunjungi. Jarak antara lokasi A yang terletak pada koordinat Xa Ya,dan lokasi B yang terletak pada koordinat, $X_{b} Y_{b}$ dicari dengan menggunakan rumus:

$$
\text { Dist } A\left(B_{2}\right)=\sqrt{\left(X_{a}-X_{b}\right)^{2}+\left(Y_{a}-Y_{b}\right)^{2}}
$$

\section{Penentuan Urutan Konsumen}

Pengurutan konsumen menggunakan metode farthest insert, cheapest insert, nearest neighbour, dan nearest insert. Hasil yang didapatkan dari keempat metode tersebut dibandingkan dan dipilih yang menghasilkan jarak yang minimum.

\section{Farthest Insert}

Memasukkan konsumen yang memberikan perjalanan paling jauh. Untuk setiap konsumen yang belum termasuk dalam satu rute, evaluasi kenaikan jarak tempuh yang memiliki kenaikan jarak tempuh terbesar menggunakan rumus sebagai berikut :

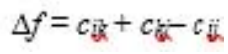

\section{Cheapest Insert}

Mulai dari depot, prosedur ini memilih konsumen yang paling dekat dengan depot. Setelah itu, membentuk rute terpendek dengan memilih yang paling minimal. Pada tiap langkah, rute dibangun dengan penyisipan menggunakan rumus, yaitu :

$$
\Delta^{f}-c_{i k}+c_{k j}-c_{i j}
$$

\section{Nearest Neighbour}

Mulai dari depot, prosedur ini menambah konsumen yang terdekat untuk melengkapi rute. Pada tiap langkah, rute dibangun dengan menambahkankonsumen yang terdekat dari titik terakhir yang dikunjungi

\section{Nearest Insert}

Memasukkan konsumen yang memberikan perjalanan terpendek. Setiap konsumen yang belum termasuk dalam satu rute, evaluasi kenaikan jarak tempuh yang memiliki kenaikan jarak tempuh terkecil menggunakan rumus, yaitu :

$$
{ }_{\Delta} J=c_{i k}+c_{k j}-c_{i j}
$$

\section{METODE PENELITIAN}

\section{Variabel}

Yang termasuk dalam indikator variabel keputusan dalam penilitian adalah sebagai berikut :

a. Rute awal distribusi

b. Lokasi retailer

c. Data jarak

d. Kapasitas kendaraan 
Variabel keputusan merupakan suatu indikator untuk mencapai variabel tujuan. Yang mana variabel tujuan adalah Biaya Distribusi

\section{Metode Analisa Data}

Pada penelitian ini, metode yang digunakan dalam menganalisa data yaitu dengan menggunakan metode saving Matrix. Metode ini bertujuan untuk menentukan rute terbaik dengan memaksimakan kapasitas kendaraan sehingga biaya distribusi dapat diminimumkan. Langkah-langkah yang dilakukan pada metode ini adalah :

1. Menetukan matrix jarak

2. Menetukan matrix penghematan

3. Mengalokasikan masing-masing kedalam rute

4. Mengurutkan titik untuk setiap rute

Berikut ini merupakan flowchart dari penelitian ini.

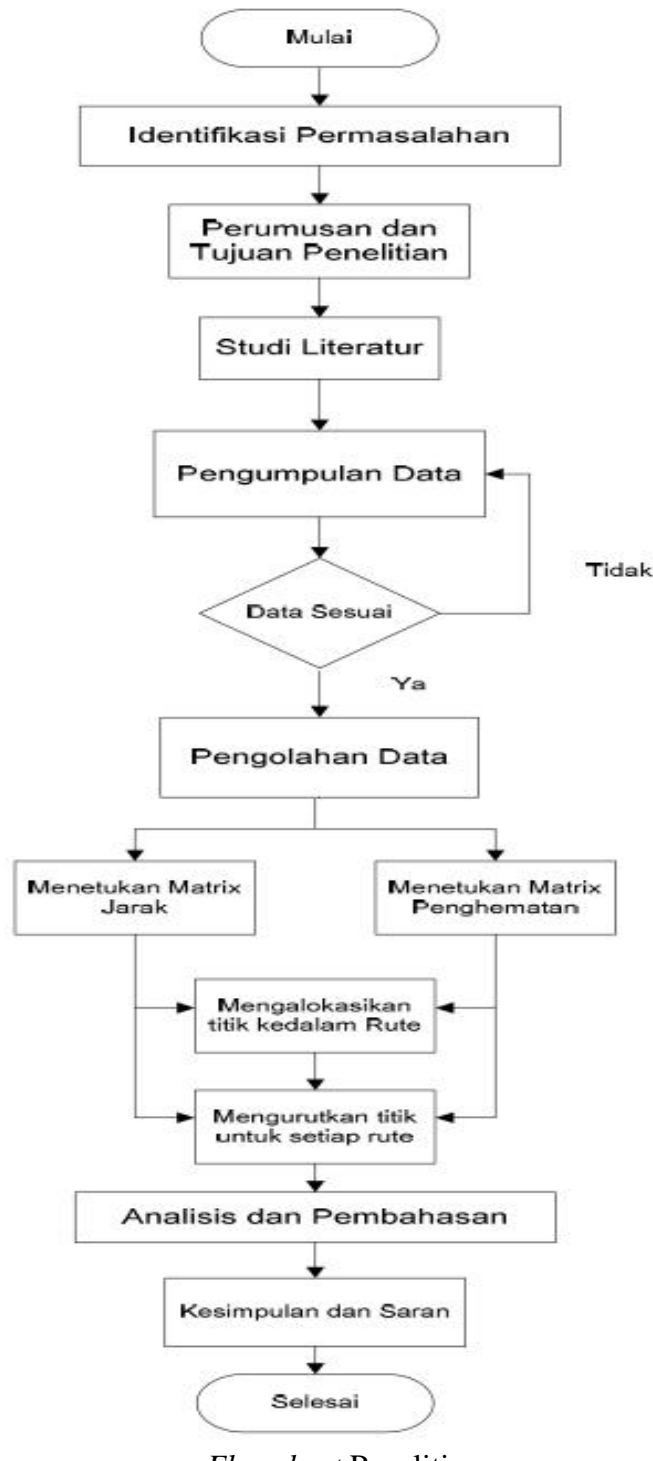

Flowchart Penelitian

HASIL DAN PEMBAHASAN

Deskripsi Sistem Distribusi Produk

Pengiriman produk pada UD. Roti Arsita berawal dan berakhir di Gudang yang sama, konsumen yang dikunjungi bisanya tergantung dari supir yang mempertimbangkan jarak konsumen dengan 
depot.Dari pabrik kemudian didistribusikan ke konsumen-konsumen. Pendistribusian dilakukan menggunkan kendaraan roda 2 yaitu Motor. Ada 5 kendaraan bermotor denan kapasitas angkut 2000 bungkus roti per kendaraan. Waktu kerja adalah selama 7 jam

Pengantaran dilakukan setiap hari kerja dengan upah perhari pengantaran Rp. 20.000 per pengantar. Rata-rata kapasitas angkut kendaraan biasanya hanya terpakai sampai $75 \%$ dari total kapasitas yang ada yaitu 1000-1500 bungkus dalam sekali pengantaran dan jika terjadi kekurangan akan diantarkan pada hari berikutnya.

Pengiriman dilakukan kepada konsumen di 14 lokasi yang berbeda, karna pendistribusian tidak ditentukan dengan pasti dalam perusahaan maka pengantar akan mendistribusiakan berdasarkan kebutuhan konsumen pada masing-masing retailer sehingga terbetuk 5 rute distribusi yaitu :

1. Depot - Tulehu - Waai - Liang - Depot

2. Depot - Poka - Waiheru - Tulehu - Tengah-tengah - Passo - Depot

3. Depot - Hitu - Laha - Depot

4. Depot - Kebun Cengkeh - Batu Merah - Ambon - Depot

5. Depot - Passo - Lateri - Batu Merah - Waihaong - Depot

Data Lokasi dan Permintaan Retailer

Data lokasi retailer yang akan dikunjungi oleh petugas distribusi terdiri dari14 lokasi yang berbeda yang pada masing-masing lokasi terdapat frekuensi permintaan yang berbeda dengan jumlah total permintaan yang tergantung pada frekuensi masing-masing lokasi retailer yang diman permintaan ratarata pada tiap retailer adalah 20 bungkus roti. Berikut merupakan daftar lokasi retailer dan total permintaa yang akan dikunjungi oleh petugas distribusi UD. Roti Arsita.

Data Lokasi Dan Permintaan Retailer

\begin{tabular}{|c|c|c|c|}
\hline No & Lokasi retailer & Frekuensi & Total Permintaan \\
\hline 1 & Tulehu & 45 & 900 \\
\hline 2 & Waai & 38 & 760 \\
\hline 3 & Liang & 35 & 700 \\
\hline 4 & Poka & 28 & 560 \\
\hline 5 & Waiheru & 18 & 360 \\
\hline 6 & Tengah-tengah & 20 & 400 \\
\hline 7 & Passo & 20 & 400 \\
\hline 8 & Hitu & 40 & 800 \\
\hline 9 & Laha & 35 & 700 \\
\hline 10 & Kebun cengkeh & 45 & 900 \\
\hline 11 & Batu merah & 40 & 800 \\
\hline 12 & Ambon & 55 & 1100 \\
\hline 13 & Lateri & 15 & 300 \\
\hline 14 & Waihaong & 35 & 700 \\
\hline
\end{tabular}


Matriks Jarak

\begin{tabular}{|r|r|r|r|r|r|r|r|r|r|r|r|r|r|r|r|}
\hline & 0 & 1 & 2 & 3 & 4 & 5 & 6 & 7 & 8 & 9 & 10 & 11 & 12 & 13 & 14 \\
\hline 0 & 0 & & & & & & & & & & & & & & \\
\hline 1 & 15.03 & 0 & & & & & & & & & & & & & \\
\hline 2 & 20.26 & 5.79 & 0 & & & & & & & & & & & & \\
\hline 3 & 23.56 & 10.36 & 5.00 & 0 & & & & & & & & & & & \\
\hline 4 & 0.37 & 15.40 & 20.62 & 23.90 & 0 & & & & & & & & & & \\
\hline 5 & 5.51 & 9.78 & 14.79 & 18.07 & 5.86 & 0 & & & & & & & & & \\
6 & 19.15 & 6.04 & 7.98 & 12.85 & 19.51 & 14.58 & 0 & & & & & & & & \\
\hline 7 & 7.56 & 7.68 & 13.25 & 17.21 & 7.92 & 3.33 & 11.65 & 0 & & & & & & & \\
\hline 8 & 8.30 & 11.61 & 15.14 & 17.11 & 8.53 & 5.03 & 17.37 & 7.90 & 0 & & & & & & \\
\hline 9 & 12.76 & 27.79 & 32.90 & 35.82 & 12.39 & 18.12 & 31.71 & 20.28 & 19.03 & 0 & & & & & \\
\hline 10 & 3.51 & 15.64 & 21.24 & 25.05 & 3.52 & 7.36 & 18.76 & 7.99 & 11.31 & 13.14 & 0 & & & & \\
\hline 11 & 3.63 & 17.31 & 22.84 & 26.50 & 3.45 & 8.55 & 20.60 & 9.63 & 11.92 & 11.28 & 1.86 & 0 & & & \\
\hline 12 & 5.36 & 18.71 & 24.31 & 28.08 & 5.16 & 10.22 & 21.68 & 11.06 & 13.65 & 10.68 & 3.07 & 1.74 & 0 & & \\
\hline 13 & 5.01 & 11 & 16 & 20 & 5 & 3 & 14 & 3 & 8 & 18 & 5 & 7 & 8 & 0 & \\
\hline 14 & 62.86 & 58 & 54 & 49 & 63 & 59 & 62 & 61 & 55 & 69 & 6.6 & 66 & 68 & 63 & 0 \\
\hline
\end{tabular}

\section{Saving Matrix}

Saving Matrix

\begin{tabular}{|r|r|r|r|r|r|r|r|r|r|r|r|r|r|r|}
\hline & 1 & 2 & 3 & 4 & 5 & 6 & 7 & 8 & 9 & 10 & 11 & 12 & 13 & 14 \\
\hline 1 & 0 & & & & & & & & & & & & & \\
\hline 2 & 30 & 0 & & & & & & & & & & & & \\
\hline 3 & 28 & 30 & 0 & & & & & & & & & & & \\
\hline 4 & 0 & 0 & 0 & 0 & & & & & & & & & & \\
\hline 5 & 11 & 11 & 11 & 0 & 0 & & & & & & & & & \\
\hline 6 & 28 & 31 & 30 & 0 & 10 & 0 & & & & & & & & \\
\hline 7 & 15 & 15 & 14 & 0 & 10 & 15 & 0 & & & & & & & \\
\hline 8 & 12 & 13 & 15 & 0 & 9 & 10 & 8 & 0 & & & & & & \\
\hline 9 & 0 & 0 & 0 & 1 & 0 & 0 & 0 & 2 & 0 & & & & & \\
\hline 10 & 3 & 3 & 2 & 0 & 2 & 4 & 3 & 0 & 3 & 0 & & & & \\
\hline 11 & 1 & 1 & 1 & 1 & 1 & 2 & 2 & 0 & 5 & 5 & 0 & & & \\
\hline 12 & 2 & 1 & 1 & 1 & 1 & 3 & 2 & 0 & 7 & 6 & 7 & 0 & & \\
\hline 13 & 9 & 9 & 9 & 0 & 7 & 10 & 0 & 5 & 0 & 3 & 2 & 2 & 0 & \\
\hline 14 & 20 & 29 & 37 & 0 & 9 & 20 & 9 & 16 & 6 & 0 & 0 & 0 & 5 & 0 \\
\hline
\end{tabular}

Matriks Penghematan Dari Yang Terbesar Sampai Terkecil

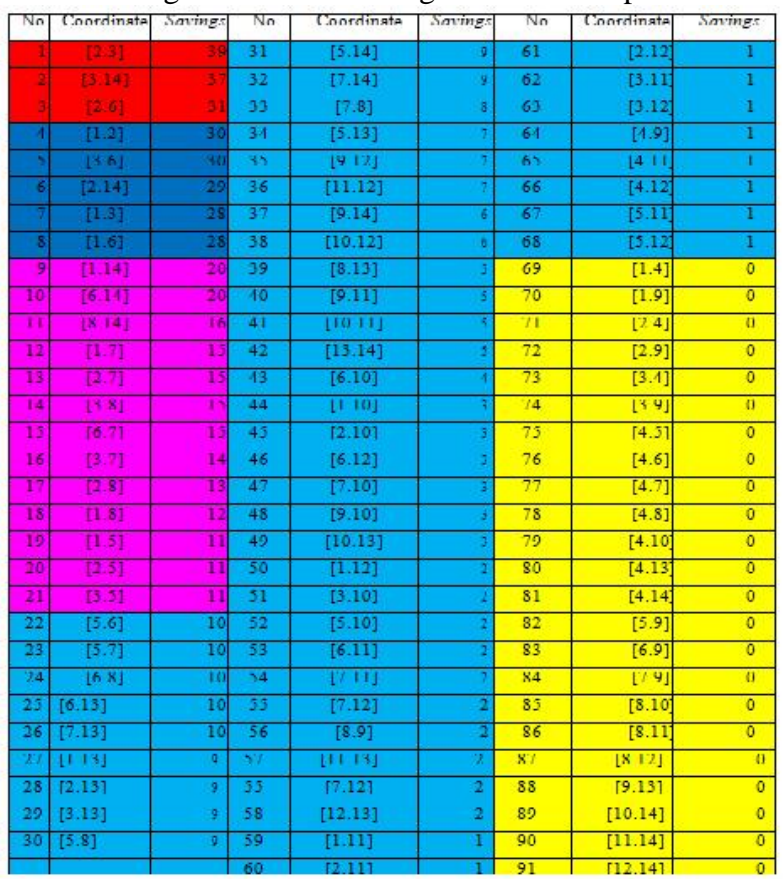


Melalui urutan penghematan dari yang terbesar sampai yang terkecil dengan mengalokasikan permintaan dengan mempertimbangkan maksimum kapasitas kendaraan kurang atau sama dengan 2000 yaitu didapatkan hasil rute baru

Rute 1 : Depot - Waai - Liang - Tengah-tengah - Depot

Beban untuk rute $1=$ Order size costumer Waai + Order size costumer Liang + Order size costumer tengah-tengah

$$
\begin{aligned}
& =760 \text { bungkus }+700 \text { bungkus }+400 \text { bungkus } \\
& =1860 \text { bungkus }
\end{aligned}
$$

Rute 2 : Depot - Tulehu - Hitu - Depot

Beban untuk rute $2=$ Order size costumer Tulehu + Order size costumer Hitu $=900$ bungkus +800 bungkus

$=1700$ bungkus

Rute 3 : Depot - Waiheru - Passo - Lateri - Waihaong - Depot

Beban untuk rute 3 = Order size costumer Waiheru + Order size costumer Passo + Order size costumer Lateri+ Order size costumer Waihaong

$=360$ bungkus +400 bungkus +320 bungkus +700 bungkus

$=1780$ bungkus

Rute 4 : Depot - Ambon - Kebun Cengkeh - Depot

Beban untuk rute $4=$ Order size costumer Kebun Cengkeh + Order size costumer Ambon $=900$ bungkus +1100 bungkus

$=2000$ bungkus

Rute 5 : Depot - Laha - Poka - Batu Merah - Depot

Beban untuk rute $5=$ Order size costumer Waihaong + Order size costumer Poka + Order size costumer Laha

$$
\begin{aligned}
& =800 \text { bungkus }+500 \text { bungkus }+700 \text { bungkus } \\
& =2000 \text { bungkus }
\end{aligned}
$$

\section{Algoritma Clarke \& Wright Savings}

Langkah-langkah yang dilakukan dalam pengerjaan dengan menggunakan Algoritma Clarke \& Wright Savings yaitu :

1. Langkah 1

Inisialisasi data jarak, data jumlah permintaan, data waktu pelayanan, kecepatan rata-rata kendaraan dan kapasitas kendaraan sebagai input yang dibutuhkan, lanjut ke langkah 2.

2. Langkah 2

Buat matriks jarak antar depot ke konsumen dan antar konsumen ke konsumen, lanjut ke langkah 3.

3. Langkah 3

Hitung nilai saving menggunakan persamaan $S(i, j)=d(D, i)+d(D, j)-d(i, j)$ untuk setiap pelanggan untuk mengetahui nilai penghematan, lanjut ke langkah 4.

4. Langkah 4

Urutkan pasangan pelanggan berdasarkan nilai saving matriks jarak dari nilai saving matriks terbesar hingga yang terkecil, lanjut ke langkah 5.

5. Langkah 5

Pembentukan tur pertama $(\mathrm{t}=1)$, lanjut ke langkah 6 .

6. Langkah 6

Tentukan pelanggan pertama yang ditugaskan pada tur dengan cara memilih kombinasi pelanggan dengan nilai saving terbesar, lanjut ke langkah 7.

7. Langkah 7

Hitung banyaknya jumlah permintaan dari konsumen yang telah terpilih. Apabila jumlah permintaan masih memenuhi kapasitas kendaraan sebesar 2000bungkus maka lanjut ke langkah 8. Apabila jumlah permintaan melebihi kapasitas kendaraan maka dilanjutkan ke langkah 11.

8. Langkah 8

Hitung total jarak, waktu perjalanan, waktu pelayanan, dan total waktu berdasarkan pelanggan yang telah terpilih, lanjut ke langkah 9.

9. Langkah 9.

Apabila total waktu $\leq 8$ jam maka pelanggan tersebut terpilih untuk ditugaskan pada tur kemudian lanjut ke langkah 10. Apabila waktu > 8 jam maka dilanjutkan ke langkah 11.

10. Langkah 10 
Pilih pelanggan selanjutnya yang akan ditugaskan berdasarkan kombinasi pelanggan terakhir yang terpilih dengan nilai saving terbesar, kembali ke langkah 7.

11. Langkah 11

Hapus pelanggan terakhir yang terpilih, lanjut ke langkah 12.

12. Langkah 12

Masukkan pelanggan yang terpilih sebelumnya untuk ditugaskan kedalam tur maka tur (t) telah terbentuk. Apabila masih ada pelanggan yang belum terpilih maka lanjut ke langkah 13. Apabila semua pelanggan telah ditugaskan maka proses pengerjaan AlgoritmaClarke \& Wright Savings telah selesai.

13. Langkah 13

\section{Hasil dan Analisa Algoritma Clarke \& Wright Savings}

A. Rute 1:0-2-3-6-0 (Depot - Waai - Liang - Tengah-tengah - Depot)

Pada rute 1 dari total kapasitas kendaraan muatan yang dibawa sebanyak 1860 bungkus roti sehingga tersisa 140 bungkus dari total kapasitas 2000 bungkus. Proses pendistribusian roti dimulai dari (0-2) yaitu depot ke lokasi Waai dengan jarak tempuh 20,26 km dan waktu tempuh 26 menit, untuk waktu pelayanan untuk masing-masing retailer maksimum 3 menit dengan jumlah retailer adalah 38 maka total waktu pelayanan yang dibutuhkan pada lokasi Waai adalah 114 menit. Waktu total kerja adalah 420 menit (7 jam) sehingga terdapat 280 menit waktu sisa yang diperlukan untuk pengantaran ke lokasi retailer selanjutanya. Kemudian pendistribusian dilakukan munuju lokasi (2-3) dari lokasi (2) Waai menuju ke Liang dengan jarak tempuh $5 \mathrm{~km}$ dan waktu tempuh 15 menit, terdapat 35 retailer sehingga total waktu pelayanan adalah 105 menit dan waktu sisa untuk pengantaran ke lokasi retailer selajutnya yaitu 160 menit. Pendistribusian kemudian dilanjutkan ke (3-6) yaitu dari lokasi (3) Liang menuju ke lokasi (6) Tengah-tengah dengan jarak tempuh $12,85 \mathrm{~km}$ dan waktu tempuh yang perlukan selama 36 menit. Dengan jumlah retailer sebanyak 20 maka waktu pelayanan adalah selama 60 menit dan memiliki waktu sisa selama 64 menit yang dimana 45 menit dipakai untuk kembali ke depot (6-0) sehingga dari total 7 jam kerja terdapat waktu sisa selama 19 menit maka waktu pendistribusian pada rute 1 dapat dikatakan layak.

Waktu Tempuh Rute 1

\begin{tabular}{|c|c|c|c|c|c|c|c|c|c|}
\hline $\begin{array}{l}\text { N } \\
\text { o. }\end{array}$ & Rute & $\begin{array}{c}\text { Jarak } \\
\text { Tempuh } \\
(\mathrm{Km})\end{array}$ & $\begin{array}{l}\text { Waktu } \\
\text { Tempuh } \\
\text { (Menit) }\end{array}$ & $\begin{array}{l}\text { Waktu } \\
\text { Pelayanan } \\
\text { (Menit) }\end{array}$ & $\begin{array}{c}\text { Total } \\
\text { Waktu } \\
\text { (Menit) }\end{array}$ & $\begin{array}{c}\text { Muatan } \\
\text { yang } \\
\text { dibawa }\end{array}$ & $\begin{array}{c}\text { Sisa } \\
\text { Kapasitas }\end{array}$ & $\begin{array}{l}\text { Waktu } \\
\text { sisa } \\
\text { (Menit) }\end{array}$ & $\begin{array}{c}\text { Kelayakan } \\
\text { Waktu }\end{array}$ \\
\hline \multirow{4}{*}{1} & $0-2$ & 20.26 & 26 & 114 & 140 & \multirow{4}{*}{$\begin{array}{c}1860 \\
\text { bungkus }\end{array}$} & \multirow{4}{*}{$\begin{array}{c}140 \\
\text { bungkus }\end{array}$} & 280 & Layak \\
\hline & $2-3$ & 5 & 15 & 105 & 120 & & & 160 & Layak \\
\hline & $3-6$ & 12.85 & 36 & 60 & 96 & & & 64 & Layak \\
\hline & $6-0$ & 19.15 & 45 & & & & & 19 & Layak \\
\hline \multicolumn{2}{|c|}{ Total } & & & & 401 & & & & \\
\hline
\end{tabular}

B. Rute 2:0-1 - 8-0 (Depot - Tulehu - Hitu)

Untuk rute 2 dari total kapasitas kendaraan muatan yang dibawa sebanyak 1700 bungkus roti sehingga tersisa 300 bungkus dari total kapasitas 2000 bungkus. Proses pendistribusian roti dimulai dari (0-1) yaitu depot ke lokasi Tulehu dengan jarak tempuh 15,03 km dan waktu tempuh 44 menit, untuk waktu pelayanan untuk masing-masing retailer maksimum 3 menit dengan jumlah retailer adalah 45 maka total waktu pelayanan yang dibutuhkan pada lokasi Waai adalah 135 menit. Waktu total kerja adalah 420 menit (7 jam) sehingga terdapat 241 menit waktu sisa yang diperlukan untuk pengantaran ke lokasi retailer selanjutanya. Kemudian pendistribusian dilakukan munuju lokasi (1-8) dari lokasi (1) Tulehu menuju ke Hitu dengan jarak tempuh 11,61 km dan waktu tempuh 59 menit. Dengan jumlah retailer sebanyak 20 maka waktu pelayanan adalah selama 120 menit dan memiliki waktu sisa selama 62 menit yang dimana 30 menit dipakai untuk kembali ke depot (8-0) sehingga dari total 7 jam kerja terdapat waktu sisa selama 32 menit maka waktu pendistribusian pada rute 2 dapat dikatakan layak. 
Waktu Tempuh Rute 2

\begin{tabular}{|c|c|c|c|c|c|c|c|c|c|}
\hline No. & Rute & $\begin{array}{c}\text { Jarak } \\
\text { Tempuh } \\
(\mathrm{Km})\end{array}$ & $\begin{array}{l}\text { Waktu } \\
\text { Tempuh } \\
\text { (Menit) }\end{array}$ & $\begin{array}{l}\text { Waktu } \\
\text { Pelayanan } \\
\text { (Menit) }\end{array}$ & $\begin{array}{l}\text { Total } \\
\text { Waktu } \\
\text { (Menit) }\end{array}$ & $\begin{array}{c}\text { Muatan } \\
\text { yang } \\
\text { dibawa }\end{array}$ & $\begin{array}{c}\text { Sisa } \\
\text { Kapasitas }\end{array}$ & $\begin{array}{l}\text { Waktu } \\
\text { sisa } \\
\text { (Menit) }\end{array}$ & $\begin{array}{c}\text { Kelayakan } \\
\text { Waktu }\end{array}$ \\
\hline \multirow{3}{*}{2} & $0-1$ & 15.03 & 44 & 135 & 179 & \multirow{3}{*}{$\begin{array}{c}1700 \\
\text { bungku } \\
s\end{array}$} & \multirow{3}{*}{$\begin{array}{c}300 \\
\text { bungkus }\end{array}$} & 241 & Layak \\
\hline & $1-8$ & 11.61 & 59 & 120 & 179 & & & 62 & Layak \\
\hline & $8-0$ & 8.30 & 30 & & & & & 32 & Layak \\
\hline \multicolumn{5}{|c|}{ Total Waktu } & 388 & & & & \\
\hline
\end{tabular}

C. Rute 3:0-5-7-13-14-0 ( Depot - Waiheru - Passo - Lateri - Waihaong - Depot)

Pada rute 3 dari total kapasitas kendaraan muatan yang dibawa sebanyak 1780 bungkus roti sehingga tersisa 220 bungkus dari total kapasitas 2000 bungkus. Proses pendistribusian roti dimulai dari (0-5) yaitu depot ke lokasi Waiheru dengan jarak tempuh 5,51 km dan waktu tempuh 16 menit, untuk waktu pelayanan untuk masing-masing retailer maksimum 3 menit dengan jumlah retailer adalah 38 maka total waktu pelayanan yang dibutuhkan pada lokasi Waai adalah 70 menit. Waktu total kerja adalah 420 menit (7 jam) sehingga terdapat 350 menit waktu sisa yang diperlukan untuk pengantaran ke lokasi retailer selanjutanya. Kemudian pendistribusian dilakukan munuju lokasi (5-7) dari lokasi (5) Waiheru menuju ke Passo dengan jarak tempuh 3,33 km dan waktu tempuh 26 menit, terdapat 20 retailer sehingga total waktu pelayanan adalah 60 menit dan waktu sisa untuk pengantaran ke lokasi retailer selajutnya yaitu 264 menit. Pendistribusian kemudian dilanjutkan ke (7-13) yaitu dari lokasi (7) Passo menuju ke lokasi (13)Pembentukan tur baru( $\mathrm{t}=\mathrm{t}+1)$, lanjut ke langkah 6.Lateri dengan jarak tempuh 63 $\mathrm{km}$ dan waktu tempuh yang perlukan selama 19 menit dengan jumlah retailer sebanyak 16 maka waktu pelayanan adalah selama 48 menit dan memiliki waktu sisa selama 197 menit. Pendistribusian dilanjutkan kembali menuju lokasi retailer (13-14) yaitu dari (13) lateri menuju ke lokasi (14) Waihaong dengan jarak tempuh $63 \mathrm{~km}$ dan waktu tempuh 30 menit. Dengan jumlah retailer sebanyak 35 maka total waktu pelayanan pada lokasi waihaong adalah 105 menit dan memiliki waktu sisa selama 62 menit yang dimana 17 menit dipakai untuk kembali ke depot (13-0) sehingga dari total 7 jam kerja terdapat waktu sisa selama 19 menit maka waktu pendistribusian pada rute 3 dapat dikatakan layak.

\begin{tabular}{|c|c|c|c|c|c|c|c|c|c|}
\hline \multicolumn{10}{|c|}{ Waktu Tempuh Rute 3} \\
\hline No. & Rute & $\begin{array}{c}\text { Jarak } \\
\text { Tempuh } \\
(\mathrm{Km})\end{array}$ & $\begin{array}{l}\text { Waktu } \\
\text { Tempuh } \\
\text { (Menit) }\end{array}$ & $\begin{array}{l}\text { Waktu } \\
\text { Pelayanan } \\
\text { (Menit) }\end{array}$ & $\begin{array}{c}\text { Total } \\
\text { Waktu } \\
\text { (Menit) }\end{array}$ & $\begin{array}{c}\text { Muatan } \\
\text { yang } \\
\text { dibawa }\end{array}$ & $\begin{array}{c}\text { Sisa } \\
\text { Kapasitas }\end{array}$ & $\begin{array}{l}\text { Waktu } \\
\text { sisa } \\
\text { (Menit) }\end{array}$ & $\begin{array}{c}\text { Kelayakan } \\
\text { Waktu }\end{array}$ \\
\hline \multirow{5}{*}{3} & $0-5$ & 5.51 & 16 & 54 & 70 & \multirow{5}{*}{$\begin{array}{c}1780 \\
\text { bungkus }\end{array}$} & \multirow{5}{*}{$\begin{array}{c}220 \\
\text { bungkus }\end{array}$} & 350 & Layak \\
\hline & $5-7$ & 3.33 & 26 & 60 & 86 & & & 264 & Layak \\
\hline & $7-13$ & 3 & 19 & 48 & 67 & & & 197 & Layak \\
\hline & $13-14$ & 63 & 30 & 105 & 135 & & & 62 & Layak \\
\hline & $14-0$ & 62.86 & 17 & & & & & 45 & Layak \\
\hline \multicolumn{5}{|c|}{ Total Waktu } & 375 & & & & \\
\hline
\end{tabular}

D. Rute 4 : 0 - 9-4-11-0 (Depot - Laha - Poka - Batu merah - Depot)

Untuk rute 4 muatan yang dibawa memaksimalkan sebanyak 2000 bungkus dari total kapasitas kendaraan. Proses pendistribusian roti dimulai dari (0-9) yaitu depot ke lokasi Laha dengan jarak tempuh $212,76 \mathrm{~km}$ dan waktu tempuh 26 menit, untuk waktu pelayanan untuk masing-masing retailer maksimum 3 menit dengan jumlah retailer adalah 40 maka total waktu pelayanan yang dibutuhkan pada lokasi Waai adalah 120 menit. Waktu total kerja adalah 420 menit (7 jam) sehingga terdapat 274 menit waktu sisa yang diperlukan untuk pengantaran ke lokasi retailer selanjutanya. Kemudian pendistribusian dilakukan munuju lokasi (9-4) dari lokasi (9) Laha menuju ke Poka dengan jarak tempuh 12,39 km dan waktu tempuh 28 menit, terdapat 28 retailer sehingga total waktu pelayanan adalah 84 menit dan waktu sisa untuk pengantaran ke lokasi retailer selajutnya yaitu 162 menit. Pendistribusian kemudian dilanjutkan ke (4-11) yaitu dari lokasi (4) Poka menuju ke lokasi (11) Batu merah dengan jarak tempuh 3,45 km dan waktu tempuh yang perlukan selama 25 menit. Dengan jumlah retailer sebanyak 40 maka waktu pelayanan adalah selama 120 menit dan memiliki waktu sisa selama 17 menit yang dimana 11 menit 
dipakai untuk kembali ke depot (11-0) sehingga dari total 7 jam kerja terdapat waktu sisa selama 6 menit maka waktu pendistribusian pada rute 1 dapat dikatakan layak.

Waktu Tempuh Rute 4

\begin{tabular}{|c|c|c|c|c|c|c|c|c|c|}
\hline No. & Rute & $\begin{array}{c}\text { Jarak } \\
\text { Tempuh } \\
(\mathrm{Km})\end{array}$ & $\begin{array}{l}\text { Waktu } \\
\text { Tempuh } \\
\text { (Menit) }\end{array}$ & $\begin{array}{c}\text { Waktu } \\
\text { Pelayanan } \\
\text { (Menit) }\end{array}$ & $\begin{array}{c}\text { Total } \\
\text { Waktu } \\
\text { (Menit) }\end{array}$ & $\begin{array}{c}\text { Muatan } \\
\text { yang } \\
\text { dibawa }\end{array}$ & $\begin{array}{c}\text { Sisa } \\
\text { Kapasitas }\end{array}$ & $\begin{array}{l}\text { Waktu } \\
\text { sisa } \\
\text { (Menit) }\end{array}$ & $\begin{array}{l}\text { Kelayakan } \\
\text { Waktu }\end{array}$ \\
\hline \multirow{4}{*}{5} & $\begin{array}{c}0- \\
9\end{array}$ & 12.76 & 26 & 120 & 146 & \multirow{4}{*}{$\begin{array}{c}2000 \\
\text { bungkus }\end{array}$} & \multirow{4}{*}{0} & 274 & Layak \\
\hline & $\begin{array}{c}9- \\
4\end{array}$ & 12.39 & 28 & 84 & 112 & & & 162 & Layak \\
\hline & $\begin{array}{l}4- \\
11\end{array}$ & 3.45 & 25 & 120 & 145 & & & 17 & Layak \\
\hline & $\begin{array}{c}11- \\
0\end{array}$ & 3.63 & 11 & & & & & 6 & Layak \\
\hline \multicolumn{5}{|c|}{ Total } & 414 & & & & \\
\hline
\end{tabular}

Perbandingan Waktu Rute Awal dan Hasil perhitungan manual dengan Algoritma Clarke \& Wright Saving

Waktu Distribusi

Untuk melihat keandalan solusi yang dihasilkan, maka dapat membandingkan solusi pada rute awal perusahaan dengan solusi yang dihasilkan dari Algoritma Clarke \& Wright Saving. Pada tabel berikut ini menunjukan hasil perbandingan rute awal perusahaan dengan solusi yang dihasilkan dari Algoritma Clarke \& Wright.

Perbandingan Waktu Rute Awal dan Algoritma Clarke \& Wright Saving

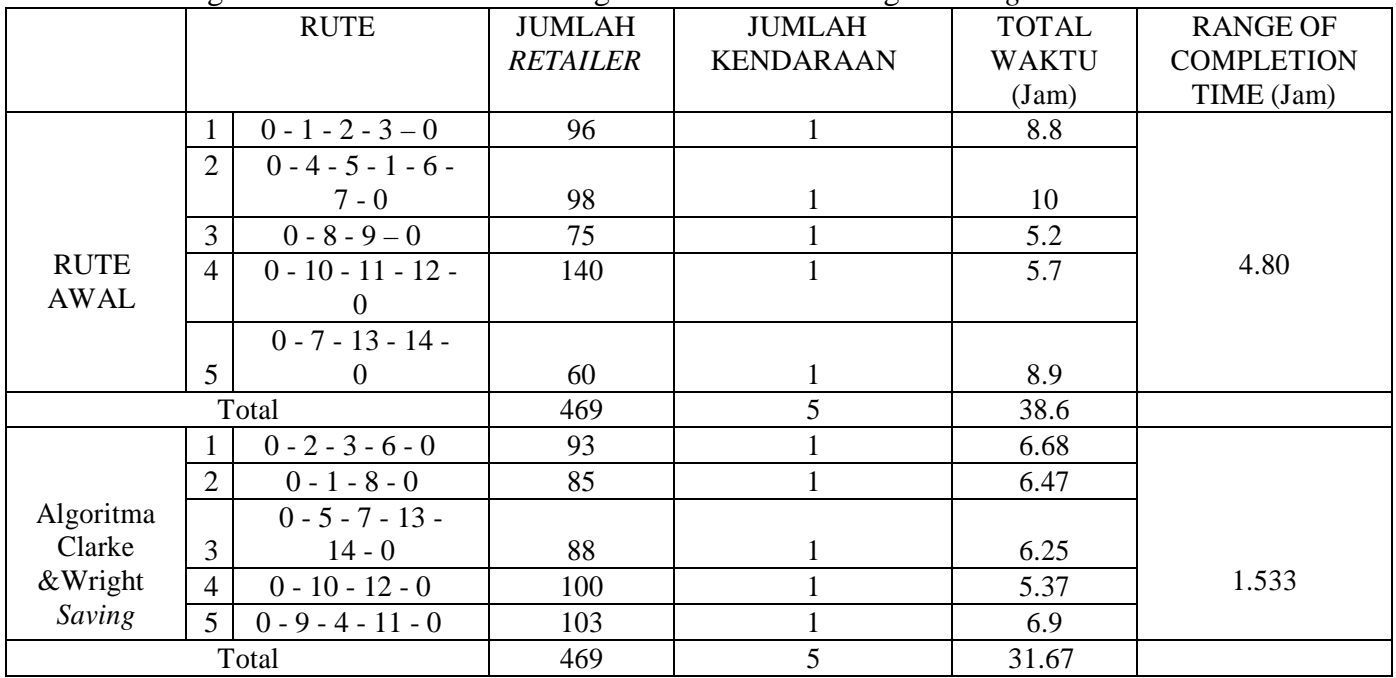

Dari tabel diatas dapat diketahui bahwa pada rute awal dan Algoritma Clarke \& Wright saving keduanya menghasilkan 5 kendaraan dengan 5 rute yang berbeda dimana total waktu durasi untuk Algoritma Clarke \& Wright saving lebih baik dari rute awal yaitu sebesar 1.533 jam dibandingkan dengan 31.67 jam. Dan untuk range of completion time Algoritma Clarke \& Wright saving juga lebih baik yaitu sebesar 1.533 jam dibandingkan dengan 4.8 jam. Sehingga dapat disipmpulkan bahwa waktu distribusi dan banyaknya retailer untuk rute awal pada dasarnya sangat berbeda antara lamanya waktu kerja tiap rute, pada rut kedua mendapatkan waktu kerja yang paling lama yaitu 10 jam dan rute keempat memiliki retailer yang terbanyak yaitu 140 retailer, dengan menggunakan Algoritma Clarke \& Wright saving untuk setiap distribusi rute waktu dan jumlah retailer untuk masing-masing rute disama ratakan. Gambar 4.2 berikut ini menunjukan grafik histogram distribusi beban kerja dari tiap kendaraan untuk ruteawal dan Algoritma Clarke \& Wright saving. 


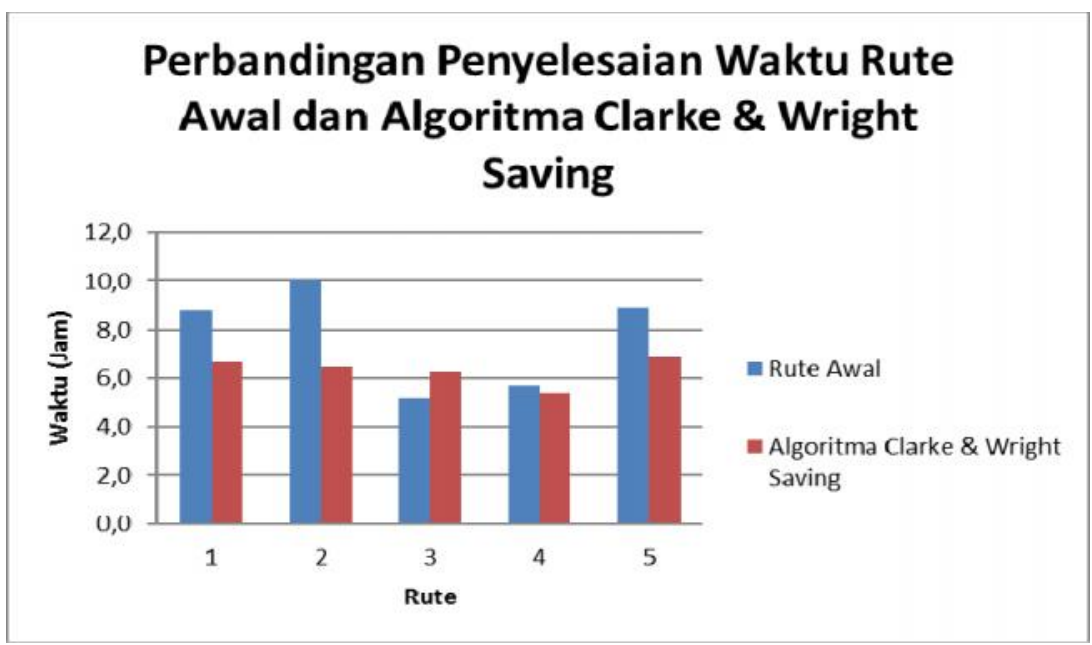

Grafik Perbandingan Penyelesaian Waktu Rute Awal dan Algoritma Clarke \& Wright Saving Biaya Distribusi

Rute awal

Biaya tenaga kerja : Rp. 20.000 / hari

Biaya Bahan bakar $=$ jarak tempuh $\mathrm{x} 1 / 34$ liter $\mathrm{x}$ harga bahan bakar/liter

1. Rute $1=98,74 \mathrm{~km} \times 1 / 34$ x Rp 6.550

Rp. $19.022,40818$

2. Rute $2=82,53 \mathrm{~km} \times 1 / 34 \times \mathrm{Rp} 6.550$

$=$ Rp. $15.898,43272$

3. Rute $3=80,18 \mathrm{~km} \times 1 / 34 \times \mathrm{Rp} 6.550$

$=$ Rp. 15.445,73508

4. $\quad$ Rute $4=2,721 \mathrm{~km} \times 1 / 34 \times \mathrm{Rp} 6.550$

$=$ Rp. 524,2421

5. Rute $5=271,81 \mathrm{~km} \times 1 / 34 \times \operatorname{Rp} 6.550$

$=$ Rp. 52.362,98226

Total biaya bahan bakar

$=$ Rp. $19.022,40818+$ Rp. $15.898,43272+$ Rp. $15 \cdot 445,73508+$ Rp. $524,2421+$ Rp. $52 \cdot 362,98226$

$=$ Rp. $103.253,8004$

Biaya Total $/$ hari $=$ Total biaya tenaga kerja + Total biaya bahan bakar

$=$ Rp. 20.000 (5) + Rp. 103.253,8004

$=$ Rp. $203.253,8004$

Biaya total $/$ bulan $=154.037,5 \times 30$ hari $=$ Rp. $6.097 .614,012$

Rute Sesudah Penerapan Algoritma Clarke \& Wright Saving

1. Rute $1=57.25 \mathrm{~km} \times 1 / 34$ x Rp. 6550

Rp. 15.373,23

2. Rute $2=34.94 \mathrm{~km} \times 1 / 34$ x Rp. 6550

$=$ Rp. 13.292,64

3. Rute $3=137.7 \mathrm{~km} \times 1 / 34$ x Rp. 6550

$=$ Rp. $8 \cdot 283,82$

4. $\quad$ Rute $4=11.94 \mathrm{kn} \times 1 / 34 \times$ Rp. 6550

$=$ Rp. 3313,52

5. Rute $5=32.23 \mathrm{~km} \times 1 / 34 \times$ Rp. 6550

$=$ Rp. $10.441,47$

Total biaya bahan bakar

$=$ Rp. $15 \cdot 373,23+$ Rp. $13 \cdot 292,64+$ Rp. $8 \cdot 283,82+$ Rp. $3313,52+$ Rp. $10.441,47$

$=$ Rp. 52.700

Biaya Total $/$ hari $=$ Total biaya tenaga kerja + Total biaya bahan bakar

$=$ Rp. $20.000(5)+$ Rp. 52.700

$=$ Rp. 152.700

Biaya total $/$ bulan $=$ Rp. $152.700 \times 30$ hari $=$ Rp. $4.581 .002,384$ 
Perbandingan Biaya Rute Awal dan Algoritma Clarke \& Wright Saving

\begin{tabular}{|c|c|c|c|c|c|}
\hline \multicolumn{3}{|c|}{ Rute awal } & \multicolumn{3}{|c|}{ Rute saving matrix } \\
\hline Rute & $\begin{array}{l}\text { Total jarak } \\
(\mathrm{Km})\end{array}$ & $\begin{array}{c}\text { Biaya Bahan } \\
\text { Bakar (Rupiah) }\end{array}$ & Rute & $\begin{array}{l}\text { Total Jarak } \\
(\mathrm{Km})\end{array}$ & $\begin{array}{l}\text { Biaya Bahan Bakar } \\
\text { (Rupiah) }\end{array}$ \\
\hline 1 & 98,74 & 19022,40818 & 1 & 57,25 & 11029,19422 \\
\hline 2 & 82,53 & 15898,43272 & 2 & 34,94 & 6731,595789 \\
\hline 3 & 80,18 & 15445,73508 & 3 & 137 & 26428,69257 \\
\hline 4 & 2,721 & 524,2421394 & 4 & 11,94 & 2299,755239 \\
\hline 5 & 271,81 & 52362,98226 & 5 & 32 & 6210,841657 \\
\hline & 535,97 & 103253,8004 & & 273,56 & 52700,07948 \\
\hline \multicolumn{2}{|c|}{ Biaya Total } & 203253,8004 & \multicolumn{2}{|c|}{ Biaya Total } & 152700,0795 \\
\hline \multicolumn{2}{|c|}{ Biaya Total/bulan } & 6097614,012 & \multicolumn{2}{|c|}{ Biaya Total/bulan } & 4581002,384 \\
\hline
\end{tabular}

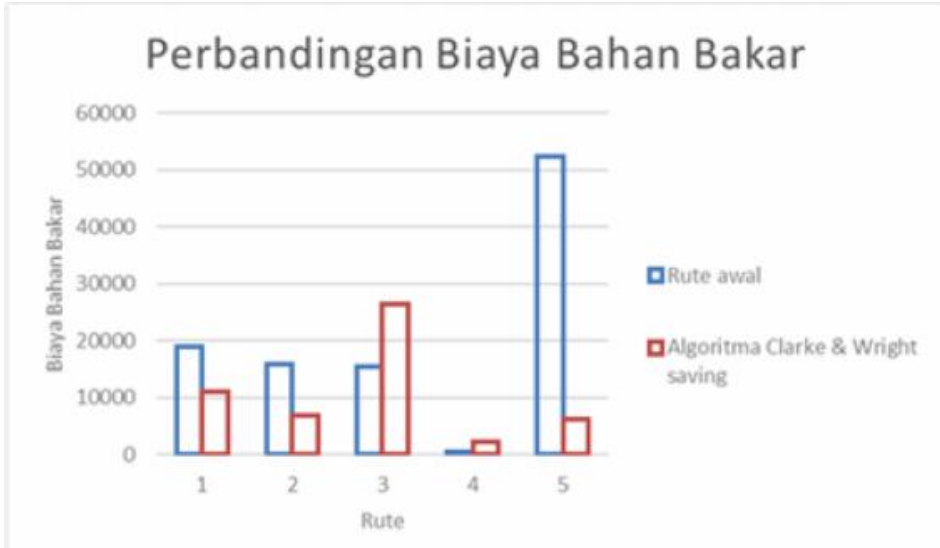

Gafik Perbandingan bahan bakar tiap rute

Dari grafik diatas dapat diketahui bahwa pada rute awal yang ditandai dengan warna biru dan warna merah untuk Algoritma Clarke \& Wright Saving. Pada rute 1, rute 2, dan rute 5 biaya bahan bakan rute awal lebih besar dari rute Algoritma Clarke \& Wright Saving, sebaliknya untuk rute 3 dan rute 4 biaya bahan bakar rute awal lebih besar dari yang dimiliki rute Algoritma Clarke \& Wright Saving. Selain itu rute awal beroperasi sebanyak 2 hari dengan rute yang sama tetapi retailer yang berbeda oleh karen itu pada Algoritma Clarke \& Wright Saving retailer pada semua lokasi digabungkan sehingga pengoperasiaan kendaraan yang dilakukan dalam 2 hari dapat dikurangi menjadi 1 hari pengantaran yang berpengaruh pada total biaya biaya yang dikeluarkan perusahaan dalam sebulan, dari total 30 hari kerja menjadi 15 hari kerja. Dapat dilihat pada grafik gambar berikut

\section{Perbandingan Total Biaya Bahan Bakar/Bulan}

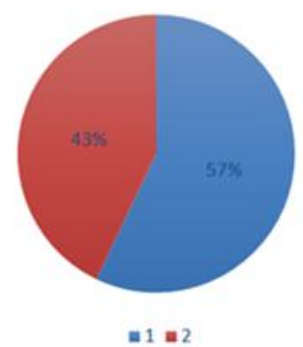




\section{Analisis Sensitivitas}

Analisis sensitivitas adalah suatu analisa untuk dapat melihat pengaruh- pengaruh yang akan terjadi akibat keadaan yang berubah-ubah (Gittinger 1986 dalam Susilowati 2018). Perubahan yang terjadi jika konsumen dari UD. Roti Arsita bertambah sehingga permintaan akan bertambah atau jika konsumen berkurang maka permintaan akan berkurang.

Data Permintaan Sensitivitas

\begin{tabular}{|c|c|c|c|c|c|c|}
\hline \multirow[b]{2}{*}{ No } & \multirow[b]{2}{*}{ Lokasi } & \multicolumn{5}{|c|}{ Jumlah Permintaan } \\
\hline & & Awal & $\begin{array}{l}\text { Naik } \\
25 \%\end{array}$ & $\begin{array}{l}\text { Naik } \\
50 \%\end{array}$ & $\begin{array}{c}\text { Turun } \\
25 \%\end{array}$ & $\begin{array}{c}\text { Turun } \\
25 \%\end{array}$ \\
\hline 1 & Tulehu & 900 & 1125 & 1350 & 675 & 450 \\
\hline 2 & Waai & 760 & 950 & 1140 & 570 & 380 \\
\hline 3 & Liang & 700 & 875 & 1050 & 525 & 350 \\
\hline 4 & Poka & 560 & 700 & 840 & 420 & 280 \\
\hline 5 & Waiheru & 360 & 450 & 540 & 270 & 180 \\
\hline 6 & Tengah-tengah & 400 & 500 & 600 & 300 & 200 \\
\hline 7 & Passo & 400 & 500 & 600 & 300 & 200 \\
\hline 8 & Hitu & 800 & 1000 & 1200 & 600 & 400 \\
\hline 9 & Laha & 700 & 875 & 1050 & 525 & 350 \\
\hline 10 & Kebun Cengkeh & 900 & 1125 & 1350 & 675 & 450 \\
\hline 11 & Batu Merah & 800 & 1000 & 1200 & 600 & 400 \\
\hline 12 & Ambon & 1100 & 1375 & 1650 & 825 & 550 \\
\hline 13 & Lateri & 300 & 375 & 450 & 225 & 150 \\
\hline 14 & Waihaong & 700 & 1050 & 525 & 350 & 700 \\
\hline
\end{tabular}

Setelah hasil dari pengolahan data maka dilakukan pengujian validitas dari hasil tersebut, dimana pengujian dilakukan pada data permintaan outlet. Kendaraan berkapasitas 2000 bungkus roti maka dari itumasing-masing rute tidak boleh lebih dari 2000 bungkus roti karena satu rute adalah 1 kendaraan dengan batasan kapasitas. Uji validitas dihitung dengan cara menambahkan seluruh permintaan masingmasing outlet pada setiap rute dan total permintaan jika kurang atau sama dengan 2000 maka data dinyatakan valid dan jika total permintaan lebih dari 320 maka data dinyatakan tidak valid.

Hasil Pengolahan Data dalam Keadaan Permintaan Naik 25\%

\begin{tabular}{|c|c|c|c|c|c|}
\hline No & Rute & $\begin{array}{c}\text { Jarak } \\
\text { Tempuh }\end{array}$ & Waktu Tempuh & Total Permintaan & Ket \\
\hline 1 & $0-2-3-0$ & 60.26 & 82 & 1825 & Valid \\
\hline 2 & $0-4-6-7-0$ & 43.58 & 103 & 1875 & Valid \\
\hline 3 & $0-1-5-13-0$ & 46.61 & 127 & 1950 & Valid \\
\hline 4 & $0-8-9-0$ & 80.18 & 61.6 & 1875 & Valid \\
\hline 5 & $0-14-10-0$ & 61.7 & 41 & 2000 & Valid \\
\hline 6 & $0-12-0$ & 10.72 & 18 & 1375 & Valid \\
\hline 7 & $0-11-0$ & 7.26 & 22 & 1000 & Valid \\
\hline
\end{tabular}

\section{Hasil Pengolahan Data dalam Keadaan Permintaan Naik 50\%}

Dari hasil pengolahan data dalam keadaan permintaan naik 50\% diketahui bahwa dengan bertambahnya permintaan maka kendaraan yang ada sekarang tidak dapat memenuhi semua permintaan maka dapat ditambahkan 4 kendaraan pada rute baru yang terbentuk sehingga semua rute menjadi valid. 
Hasil Pengolahan Data dalam Keadaan Permintaan Naik 50\%

\begin{tabular}{|c|c|c|c|c|c|}
\hline No & Rute & Jarak Tempuh & Waktu Tempuh & $\begin{array}{c}\text { Total } \\
\text { Permintaan }\end{array}$ & Ket \\
\hline 1 & $0-4-3-0$ & 59.93 & 110 & 1890 & Valid \\
\hline 2 & $0-1-6-0$ & 25.93 & 69 & 1950 & Valid \\
\hline 3 & $0-8-5-0$ & 27.81 & 74 & 1740 & Valid \\
\hline 4 & $0-7-11-0$ & 25.19 & 65 & 1800 & Valid \\
\hline 5 & $0-10-13-0$ & 23.75 & 51 & 1800 & Valid \\
\hline 6 & $0-2-0$ & 40.52 & 52 & 1050 & Valid \\
\hline 7 & $0-9-0$ & 25.58 & 52 & 1650 & Valid \\
\hline 8 & $0-12-0$ & 17.6 & 32 & 1050 & Valid \\
\hline 9 & $0-14-0$ & 108 & 40 & & 140 \\
\hline
\end{tabular}

Hasil Pengolahan Data dalam Keadaan Permintaan Turun 25\%

Dari hasil pengolahan data dalam keadaan permintaan Turun $25 \%$ diketahui bahwa dengan berkurangnya permintaan maka rute yang terbentuk akan sesuai dengan permintaan yang diterima sehingga pada keadaan ini hanya terbentuk 4 rute yang valid.

Hasil Pengolahan Data dalam Keadaan Permintaan Turun 25\%

\begin{tabular}{|c|c|c|c|c|c|}
\hline No & Rute & $\begin{array}{c}\text { Jarak } \\
\text { Tempuh }\end{array}$ & $\begin{array}{c}\text { Waktu } \\
\text { Tempuh }\end{array}$ & $\begin{array}{c}\text { Total } \\
\text { Permintaan }\end{array}$ & Ket \\
\hline 1 & $0-2-3-6-8-0$ & 79.41 & 163 & 1995 & Valid \\
\hline 2 & $0-1-7-13-14-5-0$ & 118.54 & 176 & 1995 & Valid \\
\hline 3 & $0-9-4-10-0$ & 40.3 & 67.2 & 1620 & Valid \\
\hline 4 & $0-11-12-0$ & 14.83 & 33 & 1425 & Valid \\
\hline
\end{tabular}

\section{Hasil Pengolahan Data dalam Keadaan Permintaan Turun 50\%}

Dari hasil pengolahan data dalam keadaan permintaan Turun 50\% diketahui bahwa dengan berkurangnya permintaan maka rute yang terbentuk akan sesuai dengan permintaan yang diterima sehingga pada keadaan ini hanya terbentuk 3 rute yang valid.

Hasil Pengolahan Data dalam Keadaan Permintaan Turun 50\%

\begin{tabular}{|c|c|c|c|c|c|}
\hline No & Rute & $\begin{array}{c}\text { Jarak } \\
\text { Tempuh }\end{array}$ & $\begin{array}{c}\text { Waktu } \\
\text { Tempuh }\end{array}$ & $\begin{array}{c}\text { Total } \\
\text { Permintaan }\end{array}$ & Ket \\
\hline 1 & $0-2-3-6-8-1-7-0$ & 108.28 & 250 & 1980 & Valid \\
\hline 2 & $0-13-14-5-4-9-10-0$ & 132.12 & 181 & 1760 & Valid \\
\hline 3 & $0-11-12-0$ & 14.83 & 33 & 950 & Valid \\
\hline
\end{tabular}

\section{KESIMPULAN}

Dari hasil pengumpulan data, pengolahan data, dan pembahasan yang sudah dilakukan, kesimpulan yang diperoleh dari penelitian ini adalah sebagai berikut :

1. Rute distribusi awal pada perusahaan ada 5 yaitu:

A. Rute 1 Depot - Tulehu - Waai - Liang - Depot, dengan total jarak tempuh yaitu 98,76 km dan total waktu distribusi yaitu 8,8 jam. 
B. Rute 2 Depot - Poka - Waiheru - Tulehu - Tengah-tengah - Passo - Depot, dengan total jarak tempuh yaitu $82,52 \mathrm{~km}$ dan total waktu distribusi yaitu 10 jam.

C. Rute 3 Depot - Hitu - Laha - Depot, dengan total jarak tempuh yaitu $80,18 \mathrm{~km}$ dan total waktu distribusi yaitu 5,2 jam.

D. Rute 4 Depot - Kebun Cengkeh - Batu Merah - Ambon - Depot, dengan total jarak tempuh yaitu $2,73 \mathrm{~km}$ dan total waktu distribusi yaitu 5,7 jam.

E. Rute 5 Depot - Passo - Lateri - Batu Merah - Waihaong - Depot, dengan total jarak tempuh yaitu $271,81 \mathrm{~km}$ dan total waktu distribusi yaitu 8,9 jam.

2. Rute pendistribusian produk yang diperoleh setelah melakukan perhitungan dengan menggunakan Algoritma Clake \& Wright Saving untuk masing-masing rute adalah sebagai berikut:

A. Rute 1:0-2-3-6-0 (Depot - Waai - Liang - Tengah- tengah - Depot), dengan total jarak tempuh yaitu $57,25 \mathrm{~km}$ dan total waktu distribusi yaitu 6,68 jam.

B. Rute 2:0-1 - 8-0 (Depot - Tulehu - Hitu), dengan total jarak tempuh yaitu 34,94 km dan total waktu distribusi yaitu 6,47 jam.

C. Rute 3:0 - 5 - 7 - 13-14 - 0 ( Depot - Waiheru - Passo - Lateri - Waihaong - Depot), dengan total jarak tempuh yaitu $137 \mathrm{~km}$ dan total waktu distribusi yaitu 6,25 jam.

D. Rute 4:0 - $10-12$ - 0 (Depot - Kebun Cengkeh - Ambon - Depot), dengan total jarak tempuh yaitu $11,94 \mathrm{~km}$ dan total waktu distribusi yaitu 5,37 jam.

E. Rute 5 : 0 - 9-4-11-0 (Depot - Laha - Poka - Batu merah - Depot), dengan total jarak tempuh yaitu $32 \mathrm{~km}$ dan total waktu distribusi yaitu 6,9 jam.

3. Perolehan rute awal perusahaan sebesar 535,97 km sedangkan dengan metode Algoritma Clake \& Wright Saving sebesar 273,56 km sehingga adanya nilai penghematan jarak sebesar 262,42 km atau 48\%. Dari perhitungan total biaya distribusi rute awal adalah sebesar Rp 6.097.614,012 per bulan dan total biaya distribusi menggunakan Algoritma Clake \& Wright Saving adalah Rp 4.581.002 per bulan dan diperoleh penghemantan biaya per bulan sebesar Rp 1.516.612 per bulan atau sebesar 24,8\% per bulan. Sehingga dengan menggunakan Algoritma Clake \& Wright Saving bisa didapatkan biaya distribusi yang lebih minimum.

\section{DAFTAR PUSTAKA}

Bowersox, Donald J. (2006)., Manajemen Logistik. Jilid I. Cetakan Kelima. Jakarta : PT Bumi Aksara.

Bowersox, Donald J. (1995)., Manajemen Logistik 2 (Integrasi Sistem-sistem Manajemen Distribusi Fisik dan Manajemen Material). Jakarta : Bumi Aksara

Evelyn, Susanty dan Puspitasari Diana. (2015). Penentuan Distribusi Optimal Menggunakan Metode Saving Matrix untuk Meningkatkan Fleksibilitas Pemesanan. Semarang : Universitas Diponegoro.

Effendi, Ahmad. (2016)., Penentuan Rute Optimal Distribusi Produk Dengan Metode Saving Matrix dan Traveling Salesman Problem di PT. Romindo Primavetcom. Jawa Timur : FTI-UPN "Veteran"

Hutabarat, Julianus. (2008)., Penentuan Jalur Distribusi pada Rantai Supply Dengan Metode Saving Matrix.Surabaya : Prosiding Seminar Nasional Manajemen Teknologi VIII.

Ikfan, Noer dan Ilyas Masudin. (2013)., Penentuan Rute Transporasi Terpendek untuk Meminimalkan Biaya Menggunakan Metode Saving Matrix. Malang: Universitas Muhammadiyah Malang

Kotler, Philip, (2000)., Marketing Management. Edisi Milenium, Pretice Hall Intl, Inc New Jersey

Nusmese. P., Rahawarin .A., Paillin, D.B., (2016)., Usulan Penentuan Rute Dalam Pendistribusian Bbm Bersubsidi (Premium) pada PT. Pertamina TBBM Wayame Ambon ke SPBU di Pulau Ambon Dengan Pendekatan Vehicle Routing Problem, Jurnal ARIKA, Vol.10 No.1, pp. 1-14

Pujawan, I., N., dan Mahendrawati. (2010)., Supply Chain Management, EdisiKedua, Guna Widya, Surabaya.

Suparjo. (2017)., Metode Saving Matrix Sebagai metode Alternatif Untuk Efisiensi Biaya distribusi. Semarang: Media Ekonomi dan Menejemen

Sari, M.. (2016)., Penyelesaian Capacitated Vehicle Routing Problem Menggunakan Saving Matriks, Sequential Insertion,Dan Nearest Neighbour Di Victoria Ro. Yogyakarta : Universitas Negeri Yogyakarta

Susilowati, Etty dan Haruni Kurniati. (2018)., Analisis Kelayakan dan Sensitivitas: Studi Kasus Industri Kecil Tempe Kopti Semanan. Jakarta Barat : BISMA (Bisnis dan Manajemen)

Yunitasari, A. (2014)., Optimalisasi Rute Pengangkutan Sampah di Kabupaten Sleman Menggunakan Metode Saving Matrix. Tugas Akhir. Tidak diterbitkan. Fakultas Matematika dan Ilmu Pengetahuan Alam Universitas Negeri Yokyakarta : Yokyakarta 
Yunarti, Santi. (2013)., Pengaruh Model Core Berbasis Kontekstual Terhadap Kemampuan Pemahaman Matematika Siswa. FMIPA : STKIP Siliwangi Bandung. 